\title{
Clinical trials in Brazilian journals of ophthalmology: where we are
}

\author{
Ensaios clínicos em periódicos brasileiros de oftalmologia: onde estamos
}

Rodrigo Pessoa Cavalcantı Lira ${ }^{1,2}$, Franz Schubert Leal ${ }^{1}$, Fauze Abdulmassih Gonçalves ${ }^{1}$, Fernando Henrique Ramos Amorim ${ }^{1}$, João Paulo Fernandes Felix ${ }^{1}$, Carlos Eduardo Leite Arieta ${ }^{1}$

\begin{abstract}
Purpose: To compare clinical trials published in Brazilian journals of ophthalmology and in foreign journals of ophthalmology with respect to the number of citations and the quality of reporting [by applying the Consolidated Standards for Reporting Trials (CONSORT) statement writing standards].

Methods: The sample of this systematic review comprised the two Brazilian journals of ophthalmology indexed at Science Citation Index Expanded and six of the foreign journals of ophthalmology with highest Impact Factor ${ }^{\circledR}$ according ISI. All clinical trials (CTs) published from January 2009 to December 2010 at the Brazilians journals and a 1:1 randomized sample of the foreign journals were included. The primary outcome was the number of citations through the end of 2011. Subgroup analysis included language. The secondary outcome included likelihood of citation (cited at least once versus no citation), and presence or absence of CONSORT statement indicators.
\end{abstract}

Results: The citation counts were statistically significantly higher $(P<0.001)$ in the Foreign Group (10.50) compared with the Brazilian Group (0.45). The likelihood citation was statistically significantly higher $(P<0.001)$ in the Foreign Group $(20 / 20$ - 100\%) compared with the Brazilian Group (8/20 - 40\%). The subgroup analysis of the language influence in Brazilian articles showed that the citation counts were statistically significantly higher in the papers published in English $(P<0.04)$. Of 37 possible CONSORT items, the mean for the Foreign Group was 20.55 and for the Brazilian Group was $13.65(P<0.003)$.

Conclusion: The number of citations and the quality of reporting of clinical trials in Brazilian journals of ophthalmology still are low when compared with the foreign journals of ophthalmology with highest Impact Factor ${ }^{\circledR}$.

Keywords: Clinical trial; Ophthalmology; Citation databases; Journal Impact factor; Quality control

\section{RESUMO}

Objetivo: Comparar ensaios clínicos publicados em periódicos brasileiros de oftalmologia e em periódicos estrangeiros de oftalmologia em relação ao número de citações e à qualidade da informação [através da aplicação do Consolidated Standards for Reporting Trials (CONSORT) statement].

Métodos: A amostra desta revisão sistemática abrangeu os dois periódicos brasileiras de oftalmologia indexaoas no Science Citation Index Expanded (Grupo Brasileiro) e seis dos periódicos estrangeiros de oftalmologia com maior fator de impacto de acordo comolSI (Grupo Estrangeiro). Todos os ensaios clínicos, publicados entrejaneiro de 2009 a dezembro de 2010, nos dois periódicos brasileiros e numa amostra aleatória 1:1 dos periódicos estrangeiros foram incluídos. O desfecho primário foi o número de citações até o final de 2011. A análise de subgrupos incluiu o idioma. O desfecho secundário incluiu a probabilidade de citação (citado ao menos uma vez versus não citado), e a presença ou ausência de indicadores da declaração CONSORT.

Resultados: O número de citações foi significativamente maior $(P<0,001)$ no Grupo Estrangeiro $(10,50)$ em comparação com o Grupo Brasileiro $(0,45)$. A probabilidade de citação foi estatisticamente superior $(P<0,001)$ no Grupo Estrangeiro (20/20100\%) comparado com o Grupo Brasileiro (8/20-41\%). A análise de subgrupo sobre a influência da língua em artigos Brasileiros mostrou que o número de citações foi significativamente maior nos artigos publicados em Inglês $(P<0,04)$. Dos 37 itens do CONSORT possíveis, a média para o Grupo Estrangeiro foi de 20,55 e para o Grupo Brasileiro foi 13,65 ( $P<0,003)$.

Conclusão: O número de citações e a qualidade da redação dos ensaios clínicos em periódicos Brasileiros de oftalmologia ainda são baixos quando comparados com os periódicos estrangeiros de oftalmologia com mais alto fator de impacto.

Descritores: Ensaio clínico; Oftalmologia; Bases de dados de citações; Fator deimpacto de revistas; Controle de qualidade

\section{INTRODUCTION}

The most used tool for measuring the insertion of a journal is an analysis of how often articles published in that journal were cited in other articles of the same or other journal, indexed in a particular database, in a given time. Although imperfect, this method is used as an indicator of the global inclusion of a journal. Few years ago, the "Arquivos Brasileiros de Oftalmologia (ABO)" and the "Revista Brasileira de Oftalmologia (RBO)" have become part of the Institute for Scientific Information (ISI) Web of Knowledge ${ }^{\circledR}$, considered the most important database of scientific citations. The result of measurement of the citations made by ISI is published in the Journal Citation Reports ${ }^{\circledR}(J C R)$ which contains several indicators, the best known being the Impact Factor ${ }^{\circledR}$. The Impact Factor ${ }^{\circledR}$ of a journal in a given year is calculated based on the number of times articles published in the journal in the two previous years were cited in that year by all journals in that database ${ }^{(1)}$.

A clinical trial is a type of research study that tests how well new medical approaches work in people. These studies test new methods of screening, prevention, diagnosis, or treatment of a disease. Clinical trials, when appropriately designed, conducted, and reported, represent the gold standard in evaluating healthcare interventions ${ }^{(2)}$. The Consolidated Standards of Reporting Trials Group (CONSORT) statement provides a 25 -item checklist for a minimum set of recommendations for reporting the trial design, analysis, and results. It was
Submitted for publication: October 5,2012

Accepted for publication: November 14, 2012

Study carried out at Faculdade de Ciências Médicas da Universidade Estadual de Campinas UNICAMP.

Physician, Department of Ophthalmology, Universidade Estadual de Campinas - UNICAMP - Campinas (SP), Brazil.

Physician, Department of Ophthalmology, Universidade Federal de Pernambuco - UFPE - Recife (PE), Brazil.
Funding: No specific financial support was available for this study.

Disclose of potential conflict of interest: R.P.C.Lira, None; F.S.Leal, None; F.A.Gonçalves, None; F.H.R.Amorim, None; J.P.F.Felix, None; C.E.L.Arieta, None.

Correspondence address: Rodrigo Pessoa Cavalcanti Lira. Rua Irmã Maria David, 200 - Apto. 1302 - Recife (PE) - 52061-070 - Brazil - E-mail: rodrigopclira@hotmail.com

Comissão de Ética e Pesquisa da Universidade Estadual de Campinas: Dispensa de apresentação segundo ofício 448/2012. 
developed to assist authors in writing reports of clinical trials, editors and peer reviewers in reviewing manuscripts for publication, and readers in critically appraising published articles. It gives guidance for reporting all clinical trials, but focuses on the most common design type-individually randomized, two group, parallel trials, which accounts for over half of trials in the literature ${ }^{(3)}$.

The main purpose of this study is to compare clinical trials published in Brazilians ophthalmology journals and in foreign ophthalmology journals with respect to the number of citations and the quality of reporting (by applying the CONSORT statement writing standards).

\section{METHODS}

This study was a systematic review. Originals clinical trials phase III or phase IV were identified by retrospective review of articles published from January 2009 to December 2010 (2009/2010). Phase III trials compare the results of people taking a new treatment with the results of people taking the standard treatment. Phase IV trials are done using thousands of people after a treatment has been approved and marketed, to check for side effects that were not seen in the phase III trial.

One group (Brazilian Group) included the two Brazilian journals of ophthalmology indexed at Science Citation Index Expanded ("Arquivos Brasileiros de Oftalmologia" e "Revista Brasileira de Oftalmologia"), and the other group (Foreign Group) included six of the foreign journals of ophthalmology with highest Impact Factor ${ }^{\circledR}$ according ISI (Ophthalmology; American Journal of Ophthalmology; Archives of Ophthalmology; Investigative Ophthalmology and Vision Science; Journal of Cataract and Refractive Surgery; and British Journal of Ophthalmology) $)^{(4)}$.

The Brazilian group included all 20 clinical trials published in 2009/2010 (5-24). The Foreign group included a randomized (random order with a computer generated random number) sample of 20 clinical trials among the 449 published in 2009/2010 [The Medline search strategies for clinical trial sought (publication type) was: "clinical trial"; or "clinical trial, phase III"; or "clinical trial, phase IV"; or "controlled clinical trial"] ${ }^{(25-44)}$. All articles were carefully scrutinized to confirm the study design.

The primary outcome was the number of citations through the end of $2011^{(4)}$. Most articles are rarely cited, if at all, during the same year in which they were published, but the citation count of the 2 subsequent years is representative (it forms the basis of estimating journal impact factors). Subgroup analysis included language.

The secondary outcome included likelihood of citation (cited at least once versus no citation), and presence or absence of CONSORT statement indicators ${ }^{(3)}$. Although the CONSORT checklist has 25 items, our final grading scale had a maximum of 37 possible points, because there are general items divided in subparts. It was assigned 1 point per subpart.

Descriptive statistics were calculated. Continuous data were expressed as mean values, standard deviation (SD) and ranges. Independent sample t-test of equality of means was used to compare the 2 groups. Analyses were conducted using PSPP statistical software. $P$ values are 2 -tailed. Statistical significance was considered the 0.05 level.

\section{RESULTS}

The citation counts were statistically significantly higher $(P<0.001)$ in the Foreign Group (mean=10.50, SD=11.22, with a range from 1 to 42) compared with the Brazilian Group (mean=0.45, SD=0.60, with a range from 0 to 2) (Figure 1). The likelihood citation was statistically significantly higher $(P<0.001)$ in the Foreign Group $(20 / 20-100 \%)$ compared with the Brazilian Group (8/20 - 40\%).

The subgroup analysis of the language influence in Brazilian articles showed that the citation counts were statistically significantly hi- gher $(\mathrm{P}<0.04)$ in the papers published in English (mean $=1.00, \mathrm{SD}=0.82$, with a range from 0 to 2) compared with the papers published in Portuguese (mean $=0.31, \mathrm{SD}=0.48$, with a range from 0 to 1 ) (Figure 2 ).

Of 37 possible CONSORT items, the mean for the Foreign Group was 20.55 (54\%), SD=5.07, with a range from 11 to 29 (30\%-78\%), and for the Brazilian Group was 13.65 (35\%), SD=3.44, with a range from 8 to 21 (22\%-57\%). The difference was statistically significant $(\mathrm{P}<0.003)$ (Figure 3).

\section{DISCUSSION}

The results of this study demonstrated that the number of citations and quality of reporting of Brazilian journals of ophthalmology still are low when compared with the foreign journals of ophthalmology with higher Impact Factor. The situation is worse to the articles published in Portuguese. By analyzing the citation of articles according to the language in which they were published, it

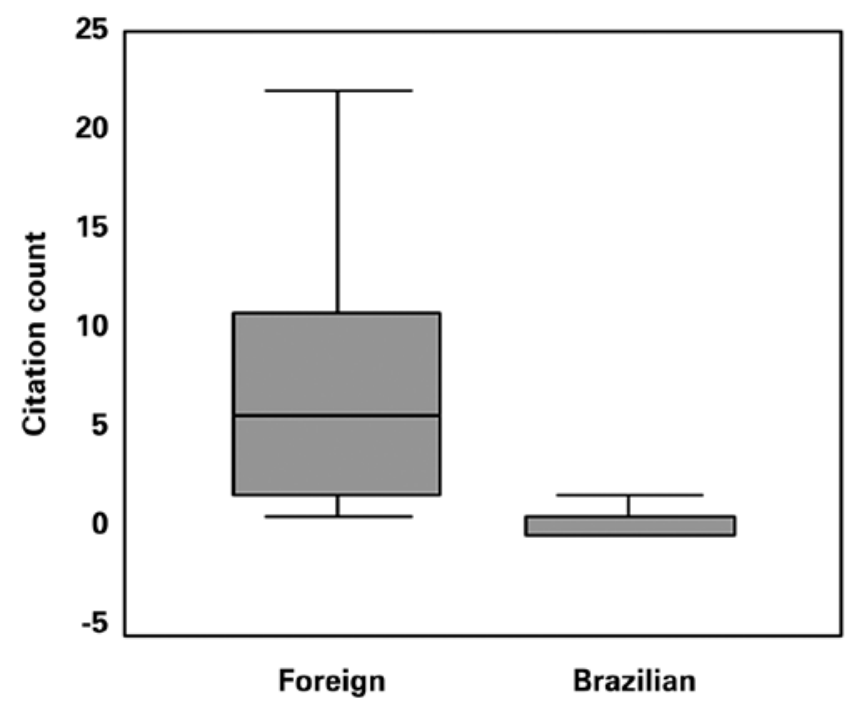

Figure 1. Citation counts of Foreign Group compared with the Brazilian Group.

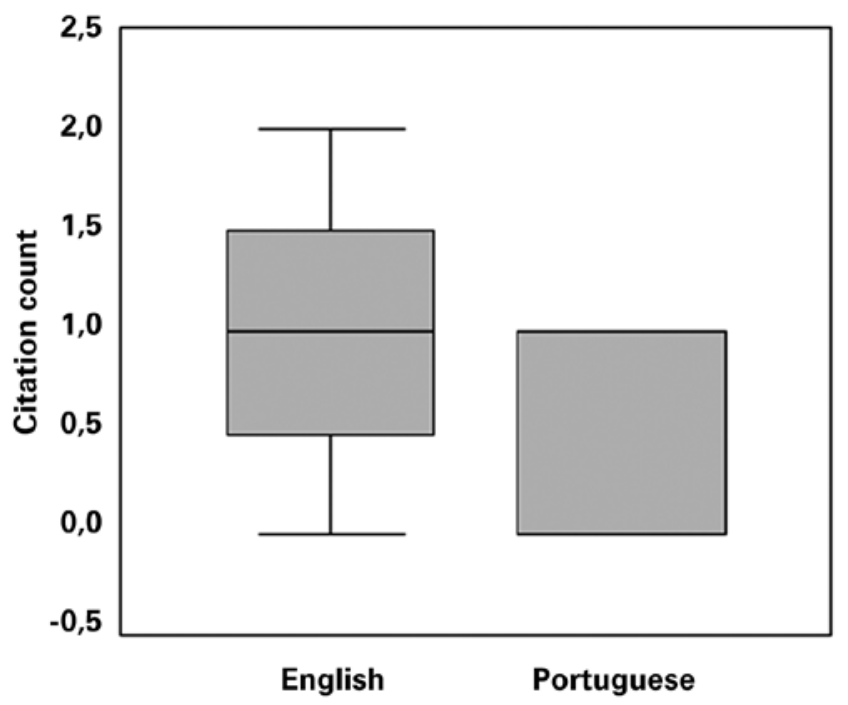

Figure 2. Subgroup analysis of the language influence in Brazilian articles. 


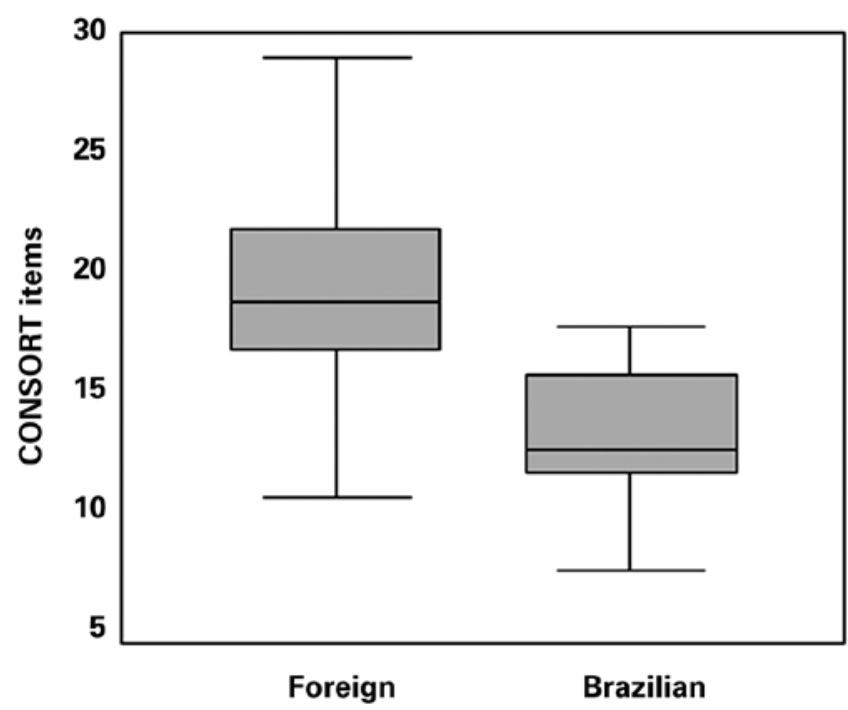

Figure 3. Presence of CONSORT statement indicators in the Foreign Group compared with the Brazilian Group.

is possible notice that the number of citations of papers written in English is higher ${ }^{(1)}$.

Citation analysis of ophthalmology articles has rarely been reported. The impact of a published article can be estimated by evaluating how frequently the study is cited in subsequent peer-reviewed publications ${ }^{(45)}$. The number of times an article is cited over a given time period might indicates the level of importance attributed to its findings by research medical community ${ }^{(46)}$. Researchers around the world rank their choices of journals for publication according to Impact Factor ${ }^{\circledR}$. The Coordination of Improvement of Higher Education Personnel (CAPES), which is the government agency in the Ministry of Education responsible for coordinating the post-graduation programs in Brazil, stratified the quality of the journals based exclusively from the ISI Impact Factor ${ }^{\circledR(1)}$.

One of the actions to reach a higher number of citations on CTS may be to embrace principles of the CONSORT ${ }^{(47)}$. The evidence-based approach that has been used for CONSORT also served as a model for development of other reporting guidelines, such as for reporting systematic reviews and meta-analysis of studies evaluating interventions (PRISMA) ${ }^{(48)}$, and Strengthening the Reporting of Observational Studies in Epidemiology (STROBE)(49). However, as a potential drawback, a reporting guideline might encourage some authors to report fictitiously the information suggested by the guidance rather than what was actually done. Readers, peer reviewers, and editors should vigilantly guard against that potential drawback and refer, for example, to trial protocols, to information on trial registers, and to regulatory agency websites. Moreover, in some cases, the CONSORT can led to improvements in reporting but not in methodological conduct ${ }^{(50)}$.

Some caveats of this study should be discussed. First, we compared the national journals versus a sample of the most important foreign journals. However, the encouragement of our Brazilian scientific community toward the highest standards of study conduct and reporting is a realistic and important goal. Second, we can not generalize the results because we analyzed only CTs. But this study design, jointly with meta-analysis, is considered the gold standard for clinical research ${ }^{(51)}$. Third, a citation does not guarantee the respect of the citing investigators. Occasionally a study may be cited only to be criticized or dismissed. Nevertheless, citation still means that the study is active in the scientific debate. Moreover, we should acknowledge that number of citation does not necessarily translate into clinical or scientific impact ${ }^{(40)}$. Fourth, a presumable circumstance that may had contributed to the low citation of papers from the Brazilian journals was its relative low IF [in 2011, the IF of ABO was 0.326, and the IF of RBO was 0.129] in comparison to the group of the foreign journals (in 2011, the average of IF was 3.692), because there is a tendency of authors to publish their best articles in journals with higher IF, perpetuating this situation ${ }^{(4)}$. Finally, for the same reason above, Brazilians authors used to publish its best articles in foreign journals. Amazingly, in a paper applying the CONSORT and STROBE statements to evaluate the reporting quality of neovascular age-related macular degeneration studies the highest reporting scores were achieved by Brazilians articles published in foreign journals ${ }^{(48)}$.

The boards of the Brazilians journals of ophthalmology are doing efforts to change this current unfavorable picture because they know the editorial scenario is competitive ${ }^{(1,52-55)}$. Although the $\mathrm{ABO}$ and RBO have not yet officially adopted the CONSORT, neither the English language, they encourage its use as well as other protocols such as STROBE and PRISMA. This attitude may contribute to the improvement of Brazilian journals global insertion.

\section{REFERENCES}

1. Chamon W, Melo Jr LA. Impact factor and insertion of the $A B O$ in the world scientific literature. Arq Bras Oftalmol [Internet]. 2011 [cited 2012 May 21];74(4):243-4. http:// www.scielo.br/pdf/abo/v74n4/v74n4a01.pdf

2. Jüni P, Altman DG, Egger M. Systematic reviews in health care: assessing the quality of controlled clinical trials. BMJ [Internet]. 2001 [cited 2011 Jan 21];323(7303):42-6.Available from: http://www.bmj.com/content/323/7303/42?view=long\&pmid=11440947

3. Moher D, Hopewell S, Schulz KF, Montori V, Gotzsche PC, Devereaux PJ, Elbourne D, Egger M, Altman DG; Consolidated Standards of Reporting Trials Group. CONSORT 2010 explanation and elaboration: updated guidelines for reporting parallel group randomised trials. J Clin Epidemiol [Internet]. 2010 [cited 2012 Jan 21];63(8):e1-37. Erratum in: J Clin Epidemiol. 2012;65(3):351. Available from: http://www.sciencedirect. com/science/article/pii/S0895435610001034

4. Web of Knowledge [Internet]. Philadelphia: Thomson Reuters. [cited 2012 Jun 30]. Available from: http://apps.webofknowledge.com

5. Fonseca Jr NL, Luci LM, Badessa MP, Rehder JR. [Comparison of two modified lidocaine solutions for local anesthesia in blepharoplasty]. Arq Bras Oftalmol [Internet]. 2009[citado 2012 Jun 21];72(2):211-4. Portuguese. Dispon: http://www.scielo.br/pdf/ abo/v72n2/15.pdf

6. Barreiro TP, Forseto AS, Pinto LF, Francesconi CM, Nosé W. [Wavefront-guided Lasik for low to moderate myopia: CustomCornea versus Zyoptix]. Arq Bras Oftalmol [Internet] 2009[cited 2010 Out 21];72(4):519-25. Portuguese. Disponível em: http://www.scielo. $\mathrm{br} / \mathrm{pdf} / \mathrm{abo} / \mathrm{v} 72 \mathrm{n} 4 / \mathrm{a} 16 \mathrm{v} 72 \mathrm{n} 4 . \mathrm{pdf}$

7. Frantz KA, Moura Filho ER, Abud MB, Avila MP, Magacho L. [Comparison of the analgesic effect between 0- MG etoricoxib and dipyrone after exeresis of primary pterygium with conjunctival autograft]. Arq Bras Oftalmol [Internet]. 2009[citado 2010 Jun 21];72(5):661-4. Portuguese. Disponível em: http://www.scielo.br/pdf/abo/ v72n5/12.pdf

8. Gonçalves RD, Cruz AA. [Oral sedation with midazolam in blepharoplasty]. Arq Bras Oftalmol [Internet]. 2009[citado 2010 Jul 21];72(5):665-8. Portuguese. Disponível em: http://www.scielo.br/pdf/abo/v72n5/13.pdf

9. Hida WT, Motta AF, Kara-José Junior N, Alves E, Tadeu M, Cordeiro LN, et al. Comparison between OPD-Scan results and visual outcomes of monofocal and multifocal intraocular lenses. Arq Bras Oftalmol [Internet]. 2009[citado 2010 Mar 21];72(4):526-32. Disponível em: http://www.scielo.br/pdf/abo/v72n4/a17v72n4.pdf

10. Kara-José Jr N, Santhiago MR, Parede TR, Espindola RF, Mazurek MG, Germano R, et al. [Influence of cataract surgical correction on working perception]. Arq Bras Oftalmol [Internet]. 2010 [citado 2011 Fev 21];73(6):491-3. Disponível em: http://www.scielo. $\mathrm{br} / \mathrm{pdf} / \mathrm{abo} / \mathrm{v} 73 \mathrm{n} 6 / \mathrm{v} 73 \mathrm{n} 6 \mathrm{a} 03 . \mathrm{pdf}$

11. Raskin E, Paula JS, Cruz AA, Coelho RP. Effect of bevel position on the corneal endothelium after phacoemulsification. Arq Bras Oftalmol [Internet]. 2010[citado 2012 Dez 21];73(6):508-10. Disponível em: http://www.scielo.br/pdf/abo/v73n6/v73n6a08.pdf

12. Rezende MP, Dias AF, Oshima A, Andrade EP, Serracarbassa PD. [Study of visual acuity and intraocular pressure in the treatment of macular diabetic edema with intravitreous triamcinolone]. Arq Bras Oftalmol [Internet]. 2010[citado 2012 Set 21]; 73(2):129-34. Disponível em: http://www.scielo.br/pdf/abo/v73n2/v73n2a06.pdf

13. Urbano AP, Nosé W. [Correction of ocular aberrations in custom and standard LASIK retreatments]. Arq Bras Oftalmol [Internet]. 2009[citado 2010 Jul 27];72(5):687-93. Portuguese. Disponível em: http://www.scielo.br/pdf/abo/v72n5/18.pdf

14. Nakano CT, Hida WT, Kara-Jose Junior N, Motta AF, Reis A, Pamplona M, et al. Comparison of central corneal edema and visual recovery between liquefaction and conventional phacoemulsification in soft cataracts. Rev Bras Oftalmol [Internet]. 2009[citado 2011 Jun 21];68(1):7-12. Disponível em: http://www.scielo.br/pdf/rbof/ v68n1/02.pdf 
15. Barreto RD, Biancardi AL, Nascimento EM, Pereira BD, de Moraes HV. Uso de ciclosporina $0,05 \%$ tópica no tratamento de olho seco de pacientes portadores do vírus HIV. Rev Bras Oftalmol [Internet]. 2009[citado 2010 Mar 19];68(2):83-9. Disponível em: http://www.scielo.br/pdf/rbof/v68n2/a04v68n2.pdf

16. Martins FC, Miyaji ME, Lima VL, Rehder JR. Biometria ultrassônica no cálculo do poder dióptrico de lentes intraoculares: estudo comparativo dos métodos de contato e de imersão. Rev Bras Oftalmol [Internet]. 2009 [cited 2010 Aug 21];68(4):212-5. Disponível em: http://www.scielo.br/pdf/rbof/v68n4/a05v68n4.pdf

17. Damasceno ED, Damasceno NA, Costa Filho AD. Ensino de oftalmologia na graduação médica. Estudo comparativo de aprendizado na oftalmoscopia direta com oftalmoscópico convencional e de campo amplo (Panoptic), Rev Bras Oftalmol [Internet]. 2009 [cited 2010 Jan 21];68(4):231-6. Disponível em: http://www.scielo.br/ pdf/rbof/v68n4/a08v68n4.pdf

18. Nakano CT, Hida WT, Kara-Jose Junior N, Motta AF, Fante D, Masson VF, et al. Comparison between OPD-scan results and contrast sensitivity of three intraocular lenses: spheric AcrySof SN60AT, aspheric AcrySof SN60WF and multifocal AcrySof Restor lens. Rev Bras Oftalmol [Internet]. 2009[citado 2010 Nov 21];68(4):216-22.Disponível em: http://www.scielo.br/pdf/rbof/v68n4/a06v68n4.pdf

19. Mendes MH, Betinjane AJ, Cavalcante AF, Castanheira VR, Cheng CT, Carani JC. Estudo comparativo entre imagens ultra-sonográficas obtidas com sondas de $10 \mathrm{MHz}$ e $20 \mathrm{MHz}$ na avaliação de anormalidades do segmento posterior do globo ocular. Rev Bras Oftalmol [Internet]. 2009[citado 2010 Jan 21];68(5):291-5.Disponível em: http://www. scielo.br/pdf/rbof/v68n5/a07v68n5.pdf

20. Portes AJ, Gomes LP, Amaral BL, Massa L. Percepção da administração tópica ocular de drogas: vaporização x gotas. Rev Bras Oftalmol [Internet]. 2009 [citado 2011 Jan 21];68(6):327-31.Disponível em: http://www.scielo.br/pdf/rbof/v68n6/ rbofv68n06a02.pdf

21. Corpa JH, Martinelli EJ, Tarcha FA, Vitiello Neto V, Ribeiro LG, Rede JR. Estudo comparativo entre desepitelização mecânica e química na ceratectomia fotorrefrativa - sintomatologia e re-epitelização pós operatória. Rev Bras Oftalmol [Internet]. 2010[citado 2012 Jun 21];69(1):23-6.Disponível em: http://www.scielo.br/pdf/rbof/ v69n1/05.pdf

22. Almodin EM, Almodin JM, Almodin FM. Avaliação corneana após "crosslink" utilizando dois tipos diferentes equipamentos. Rev BrasOftalmol [Internet]. 2010 [citdo $2011 \mathrm{Fev}$ 21];69(3):159-64.Disponível em: http://www.scielo.br/pdf/rbof/v69n3/a04v69n3.pdf

23. Pinto VC, Martini da Costa T, Grottone GT, Schor P, Pisa IT. Avaliação de um programa para computador de mão no auxílio ao ensino de oftalmologia para estudantes de medicina. Rev Bras Oftalmol [Internet]. 2010[citado 2011 Jan 23];69(6):352-60. Disponível em: http://www.scielo.br/pdf/rbof/v69n6/a02v69n6.pdf

24. Germano JE, Hida WT, Brasil AA, Germano RA, Yamane IS, Reis A, et al. Lente intraocular multifocal refrativa: a performance visual e qualidade de vida em implantes bilaterais versus unilaterais. Rev Bras Oftalmol [Internet]. 2010[citado 2011 Ago 25]; 69(6):372-7. Disponível em: http://www.scielo.br/pdf/rbof/v69n6/a05v69n6.pdf

25. Bressler NM, Chang TS, Suñer IJ, Fine JT, Dolan CM, Ward J, lanchulev T; MARINA and ANCHOR Research Groups. Vision-related function after ranibizumab treatment by better- or worse-seeing eye: clinical trial results from MARINA and ANCHOR. Ophthalmology. 2010;117(4):747-56.e4.

26. Vogel R, Crockett RS, Oden N, Laliberte TW, Molina L; Sodium Hyaluronate Ophthalmic Solution Study Group. Demonstration of efficacy in the treatment of dry eye disease with $0.18 \%$ sodium hyaluronate ophthalmic solution (vismed, rejena). Am J Ophthalmol. 2010;149(4):594-601. Comment in: Am J Ophthalmol. 2010;150(5):757; author reply 757 .

27. Pavesio C, Zierhut M, Bairi K, Comstock TL, Usner DW; Fluocinolone Acetonide Study Group. Evaluation of an intravitreal fluocinolone acetonide implant versus standard systemic therapy in noninfectious posterior uveitis. Ophthalmology. 2010;117(3): 567-75, 575.e1.

28. Domalpally A, Blodi BA, Scott IU, Ip MS, Oden NL, Lauer AK, VanVeldhuisen PC; SCORE Study Investigator Group. The Standard Care vs Corticosteroid for Retinal Vein Occlusion (SCORE) study system for evaluation of optical coherence tomograms: SCORE study report 4. Arch Ophthalmol [Internet]. 2009 [cited 2012 Nov 21];127(11):1461-7. Available from: http://www.ncbi.nlm.nih.gov/pmc/articles/PMC2788490/

29. Scott IU, Oden NL, VanVeldhuisen PC, Ip MS, Blodi BA, Antoszyk AN; SCORE Study Investigator Group. SCORE Study Report 7: incidence of intravitreal silicone oil droplets associated with staked-on vs luer cone syringe design. Am J Ophthalmol [Internet]. 2009 [cited 2012 Jan 24];148(5):725-32.e7. Available from: http://www.ncbi.nlm.nih. gov/pmc/articles/PMC2780008/

30. Boyer DS, Heier JS, Brown DM, Francom SF, lanchulev T, Rubio RG. A Phase Illb study to evaluate the safety of ranibizumab in subjects with neovascular age-related macular degeneration. Ophthalmology. 2009:116(9):1731-9. Comment in: Ophthalmology. 2010;117(9):1860; author reply 1860-1. Available from: http://ac.els-cdn.com/ S0161642009005430/1-s2.0-S0161642009005430-main.pdf?_tid=c08a3786-8d8a-11e2b888-00000aab0f26\&acdnat=1363363965 5a760f5706a3fa6af5ba0a61121bdb68

31. Korenfeld MS, Silverstein SM, Cooke DL, Vogel R, Crockett RS; Difluprednate Ophthalmic Emulsion 0.05\% (Durezol) Study Group. Difluprednate ophthalmic emulsion $0.05 \%$ for postoperative inflammation and pain. J Cataract Refract Surg. 2009;35(1):26-34. Available from: http://online.liebertpub.com/doi/pdf/10.1089/ jop.2010.0059
32. Ip MS, Oden NL, Scott IU, VanVeldhuisen PC, Blodi BA, Figueroa M, Antoszyk A, Elman M; SCORE Study Investigators Group. SCORE Study report 3: study design and baseline characteristics. Ophthalmology [Internet]. 2009[cited 2011 Jun 21];116(9):1770-7.e1. Available from: http://www.ncbi.nlm.nih.gov/pmc/articles/PMC2785028/

33. Suñer IJ, Kokame GT, Yu E, Ward J, Dolan C, Bressler NM. Responsiveness of NEI VFQ-25 to changes in visual acuity in neovascular AMD: validation studies from two phase 3 clinical trials. Invest Ophthalmol Vis Sci [Internet]. 2009 [cited 2010 Jun 21];50(8): 3629-35. Available from: http://www.iovs.org/content/50/8/3629.long

34. Kohnen T, Knorz MC, Cochener B, Gerl RH, Arné JL, Colin J, et al. AcrySof phakic anglesupported intraocular lens for the correction of moderate- to-high myopia: one-year results of a multicenterEuropean study. Ophthalmology.2009;116(7):1314-21. Available from: http://ac.els-cdn.com/S0161642009001031/1-s2.0-S0161642009001031-main. pdf? tid=308438c0-8d8b-11e2-b5d0-00000aacb362\&acdnat=1363364152 64051f1 a592253031533dd5c497333d1

35. Friberg TR, Tolentino M; LEVEL Study Group, Weber P, Patel S. Campbell S, Goldbaum M Pegaptanib sodium as maintenance therapy in neovascular age-related macular degeneration: the LEVEL study. Br J Ophthalmol [Internet]. 2010 [cited 2012 Apr 12];94:1611-7. Available from: http://www.ncbi.nlm.nih.gov/pmc/articles/PMC2991041/

36. Ehrlich JS, Manche EE. Regression of effect over long-term follow-up of conductive keratoplasty to correct mild to moderate hyperopia. J Cataract Refract Surg. 2009;35(9):1591-6. Available from: http://www.sciencedirect.com/science/article/pii/ S0886335009005616

37. Scott IU, VanVeldhuisen PC, Oden NL, Ip MS, Blodi BA, Jumper JM, Figueroa M; SCORE Study Investigator Group.SCORE Study report 1: baseline associations between central retinal thickness and visual acuity in patients with retinal vein occlusion. Ophthalmology [Internet]. 2009[cited 2010 Aug 4];116(3):504-12. Available from: http://www.ncbi.nlm.nih.gov/pmc/articles/PMC2851408/

38. Bressler NM, Chang TS, Fine JT, Dolan CM, Ward J; Anti-VEGF Antibody for the Treatment of Predominantly Classic Choroidal Neovascularization in Age-Related Macular Degeneration (ANCHOR) Research Group. Improved vision-related function after ranibizumab vs photodynamic therapy: a randomized clinical trial. Arch Ophthalmol [Internet]. 2009[cited 2011 May 24];127(1):13-21. Available from: http://archopht. jamanetwork.com/article.aspx?articleid $=420982$

39. Keane PA, Patel PJ, Ouyang $Y$, Chen FK, Ikeji F, Walsh AC, et al. Effects of retinal morphology on contrast sensitivity and reading ability in neovascular age-related macular degeneration. Invest Ophthalmol Vis Sci [Internet]. 2010[cited 2012 Oct 21]; 51(11):5431-7. Available from: http://www.ncbi.nlm.nih.gov/pmc/articles/ PMC3061494/

40. Repka MX, Kraker RT, Beck RW, Atkinson CS, Bacal DA, Bremer DL, Davis PL, Gearinger MD, Glaser SR, Hoover DL, Laby DM, Morrison DG, Rogers DL, Sala NA, Suh DW, Wheeler MB; Pediatric Eye Disease Investigator Group. Pilot study of levodopa dose as treatment for residual amblyopia in children aged 8 years to younger than 18 years. Arch Ophthalmol [Internet]. 2010 [cited 2011 Nov 24];128(9):1215-7. Available from: http://www.ncbi.nlm.nih.gov/pmc/articles/PMC3137458/

41. Abraham P Yue $H$, Wilson L. Randomized, double-masked, sham-controlled trial of ranibizumab for neovascular age-related macular degeneration: PIER study year 2. Am J Ophthalmol. 2010;150(3):315-24.e1. Available from: http://www.sciencedirect. com/science/article/pii/S0002939410002679

42. Macejko TT, Bergmann MT, Williams JI, Gow JA, Gomes PJ, McNamara TR, Abelson M Bepotastine Besilate Ophthalmic Solutions Clinical Study Group. Multicenter clinical evaluation of bepotastine besilate ophthalmic solutions $1.0 \%$ and $1.5 \%$ to treat allergic conjunctivitis. Am J Ophthalmol. 2010;150(1):122-7.e5.. Available from: http:// www.sciencedirect.com/science/article/pii/S0002939410002679

43. Campochiaro PA, Heier JS, Feiner L, Gray S, Saroj N, Rundle AC, Murashashi WY, Rubio RG; BRAVO Investigators. Ranibizumab for macular edema following branch retinal vein occlusion: six-month primary end point results of a phase III study. Ophthalmology. 2010;117(6):1102-12.e1. Available from: http://ac.els-cdn.com/S0161642010001855/ 1-s2.0-S0161642010001855-main.pdf?_tid=151d2348-8d8c-11e2-a037-00000aab0f02 \&acdnat=1363364536_7734850870a3d0d93b75d3b4e272eec3

44. Berson EL, Rosner B, Sandberg MA, Weigel-DiFranco C, Brockhurst RJ, Hayes KC, et al Clinical trial of lutein in patients with retinitis pigmentosa receiving vitamin A. Arch Ophthalmol [Internet]. 2010[cited 2012 Mar 3];128(4):403-11. Available from: http:// www.ncbi.nlm.nih.gov/pmc/articles/PMC2987594/

45. Callaham M, Wears RL, Weber E. Journal prestige, publication bias, and other characteristics associated with citation of published studies in peer-reviewed journals. J Am Med Assoc [Internet] 2002 [cited 2012 Apr 9];287:2847-50.Available from: http:// jama.jamanetwork.com/article.aspx?articleid $=194972$

46. Patsopoulos NA, Analatos AA, loannidis JPA. Relative citation impact of various study designs in the health sciences. JAMA [Internet]. 2005 [cited 2009 Set 23];293(19):2362-6. Available from: http://jama jamanetwork.com/article.aspx?articleid=200905

47. Fung AE, Palanki R, Bakri SJ, Depperschmidt E, Gibson A. Applying the CONSORT and STROBE statements to evaluate the reporting quality of neovascular age-related macular degeneration studies. Ophthalmology. 2009;116(2):286-96. Available from: http://www.sciencedirect.com/science/article/pii/S0161642008009020

48. Moher D, Liberati A, Tetzlaff J, Altman DG; PRISMA Group. Preferred reporting items for systematic reviews and meta-analyses: the PRISMA statement. BMJ [Internet]. 2009[cited 2012 May 9];339:b2535. Available from: http://www.ncbi.nlm.nih.gov/pmc/ articles/PMC2714657/ 
49. Von Elm E, Altman DG, Egger M, Pocock SJ, Gøtzsche PC, Vandenbroucke JP; STROBE Initiative. Strengthening the reporting of observational studies in epidemiology (STROBE) statement: guidelines for reporting observational studies. BMJ [Internet]. 2007;335(7824):806-8. Comment in: BMJ. 2007;335(7626):900; BMJ. 2008;144(9):1200-4 BMJ. 2007;335(7624):783-4. Available from: http://www.bmj.com/content/335/7624/ 806 ? view=long\&pmid $=17947786$

50. Ivers NM, Taljaard M, Dixon S, Bennett C, McRae A, Taleban J, et al. Impact of CONSORT extension for cluster randomised trials on quality of reporting and study methodology: review of random sample of 300 trials, 2000-8. BMJ [Internet]. 2011 [cited 2009 Mar 5];343:d5886. Available from: http://www.bmj.com/content/343/ bmj.d5886? view $=$ long\&pmid $=21948873$

51. Atkins D, Best D, Briss PA, Eccles M, Falck-Ytter Y, Flottorp S, Guyatt GH, Harbour RT, Haugh MC, Henry D, Hill S, Jaeschke R, Leng G, Liberati A, Magrini N, Mason J, Middleton P, Mrukowicz J, O'Connell D, Oxman AD, Phillips B, Schünemann HJ, Edejer T, Varonen H, Vist GE, Williams JW Jr, Zaza S; GRADE Working Group.Grading quality of evidence and strength of recommendations. BMJ [Internet]. 2004 [cited 2009 Nov 10]; 328(7454):1490. Available from: http://www.bmj.com/content/328/7454/1490?view $=$ long\&pmid $=15205295$

52. Rocha EM. A great season for internationalization of Brazilian medical research. Arq Bras Oftalmol [Internet]. 2011 [citado 2012 Jan 16];74(6):392.Disponível em: http:// www.scielo.br/pdf/abo/v74n6/a01v74n6.pdf

53. Lira RP, Arieta CE. Good reporting practices and the CONSORT. Arq Bras Oftalmol [Internet]. 2012 [cited 2013 Jan 15];75(2):85-6. Disponível em: http://www.scielo.br/ pdf/abo/v75n2/a01v75n2.pdf

54. Portes AJF. O RBO na era da informação digital. Rev Bras Oftalmol [Internet]. 2011 [citado 2012 May 18];70(1):5-6.Available from: http://www.scielo.br/pdf/rbof/ v70n1/01.pdf

55. Journal on Web. Online manuscript submission and review system. Indian Journal of Ophthalmology. Author Instructions [Internet]. [cited 2012 Jun 30]. Available from: http://www.journalonweb.com/ijo/author/instructions.asp 